\title{
Value assessment of Zamość from the perspective of 25 years on UNESCO World Heritage List
}

\author{
Joanna Jurczyk ${ }^{1}$, Bogusław Szmygin ${ }^{2}$ \\ ${ }^{1}$ graduated at University of Warsaw, e-mail: joanna.jurczyk@gmail.com \\ 2 Department of Built Heritage Protection, Lublin University of Technology, \\ e-mail: szmygin@poczta.onet.pl
}

\begin{abstract}
The historical center of Zamość was added to the UNESCO World Heritage List in 1992 and over next 25 years the city has undergone great changes. Thanks to numerous restoration, preservation and maintenance works we are now able to admire the beauty of its monuments and perfect spatial harmony. But this is not the end of planned work. Zamość Old Town is a historical part of a vibrant city and therefore needs to evolve constantly in order to satisfy the contemporary requirements of urban population. Concurrently, over that period of time theory of conservation and preservation of monuments and evaluation methodology of the value of goods inscribed on World Heritage List have developed significantly. Hence, the $25^{\text {th }}$ anniversary is a perfect occasion for a renewed evaluation of Zamość Old Town's value and more in-depth analysis in accordance with current methodology and state of knowledge. It enables further specification and indication of authentic and material carriers of its value which determine its further existence. At the same time, it will allow indicating the limits of possible interference. In addition to this, the outcome of this thorough analysis will be of great use in taking decisions on further actions and investments, which is particularly important with monuments so heterogeneous as a historical city center.
\end{abstract}

Keywords: Zamość, UNESCO List, value assessment.

\section{Characteristics of the Old Town in Zamość}

The area of the Old Town in Zamość included on the World Heritage List encompasses 75,0391 hectares. It lies within the Renaissance fortifications created by Bernardo Morando with the surrounding $19^{\text {th }}$ century fortifications. Thus, the enlisted area gathers the whole substance of the Old Town (from various periods and falling into different forms of protection) as well as the spatial plan and fortifications (original and newly reconstructed). The building substance is not homogeneous. It has various chronology, forms, legal forms of protection and practically all of it has been remodeled and reconstructed many times. ${ }^{1}$

The spatial plan of the Old Town represents in a unique way the original functional idea. The town consists of two zones: a smaller one from the West - the residential area of the tenant and a bigger one from the East - urban space (Fig. 1). The area nowadays has the shape of an irregular of a septagon. Scientists suggest, that this form is the result of gradual planning of the town and it represents a combination of a regular hexagon of urban substance with a square residence, resembling the style of Pietro Cataneo.

\footnotetext{
1 For this reason, it is very important to make a thorough analysis of the values and define the tangible carriers of the whole urban substance enlisted on the UNESCO World Heritage List. Only this approach will allow the protection of its unique value.
} 


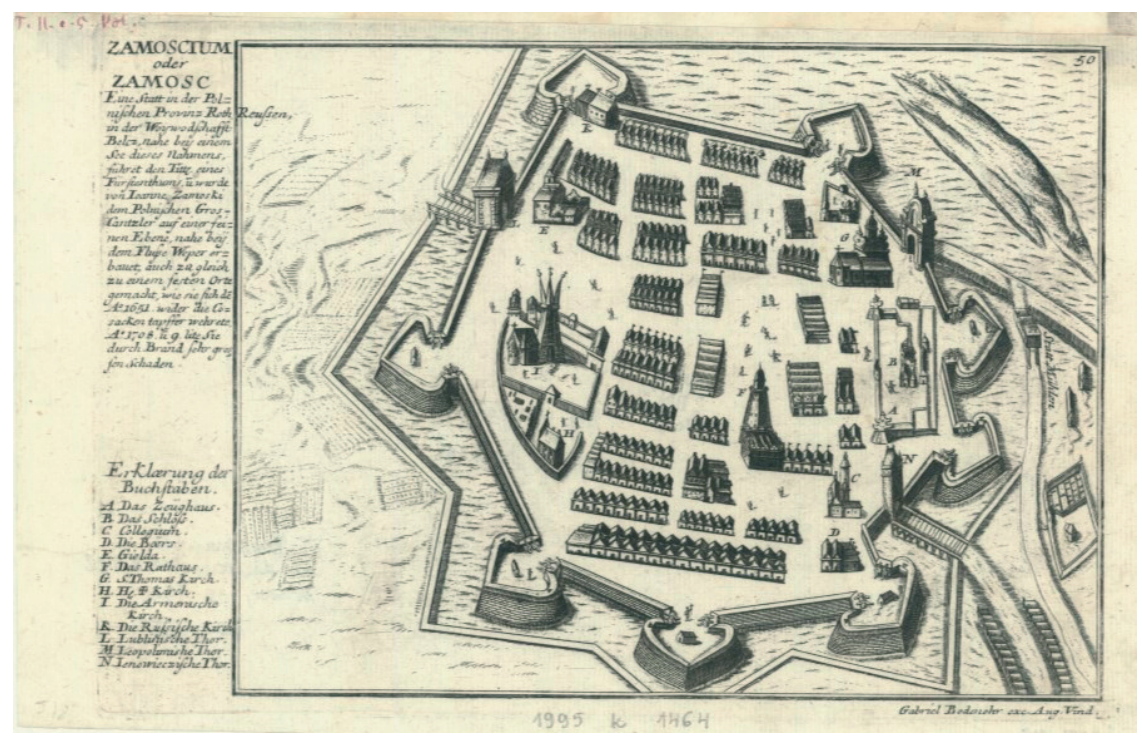

Fig. 1. Zamość city plan ca. 1605 [polona.pl]

The frontiers of the Old Town are outlined by the surrounding bastion fortification or their historical layout (if the structure did not survive until today). The design of this type of fortification was connected with the reach of the flank canister shots measuring $200 \mathrm{~m}$, which determined the maximal distance between the bastions surrounding the historical town. The bigger the urban area, the more bastions built.

Construction of the first fortifications on the turn of the 16 th century can be divided into three stages: building of the roundels and defensive walls of the palace, raising of makeshift mounds to protect the town, erection of bastion fortifications with brick reinforced slopes. The period of intense changes in the architecture of fortifications was the Austrian and Russian partition of Poland, when at the beginning of the $19^{\text {th }}$ century the fortress was profoundly reconstructed according to the projects of Malletski.

Moats were cleared, defensive walls were renovated, ravelins protecting the gate, Rotunda, earth cavaliers at necks of bastions IV, VI and VII and casemates in the rear portions of bastions V and VI as well as counter-guards in front of the bastions were erected. The defensive walls were broadened to 25-30 meters at the base and reinforced by installing shooting galleries at the superior portion of the slopes. In order to connect the fortress with the moats porters were built in the defensive walls between the bastions VII and I, I and II, III and IV, IV and V. At that time, the New Lublin Gate and the New Lviv Gate were erected. The old gates lost their original function and were adapted for prisons. The third gate - Szczebrzeszyn Gate was also rebuilt, but its function remained the same. Within $1200 \mathrm{~m}$ radius all civil structures were liquidated. Instead two mighty, bricked cavaliers were raised at the necks of the bastions VI and VII to serve as cannon battery and barracks. Important changes occurred in the outskirts (Carnot wall was raised). In the years 1836-37 four caponiers were constructed on the axis of the defensive walls IV-V, V-VI, VI-VII and VII-I. The construction works were of interest for the commander-in-chief Grand Duke Konstantin Pavlovich of Russia, who expressed his gratitude and acclamation for the engineers, during his visit in the fortress in 1823 (which by that time had for 2 years belonged to the state, not the tenant).

As result of a modernization, the fortress changed its character into strictly military: it became a huge barrack and prison (civil population was moved to Nowa Osada). Churches, the 
Academy and the Palace were changed into warehouses, barracks and lazaret. Many edifices received a stern, classic form (i.e. the tenements in the Great Square lost their attic adornments).

However, already in the 1850's the fortifications were seen as the old-fashioned, due to the fast development of artillery (among others introduction of rifled cannons). Therefore, tsar Alexander II signed on $21^{\text {st }}$ of November 1866 the decision to liquidate the fortress as not fulfilling the standards of defense.

The liquidation consisted in blowing-up parts of the fortification, tearing down the walls into the moats to level them. Most of the buildings (gates, cavaliers and Rotunda) remained intact. Lower portions of the walls and bastions, that remained under the rubbles, became later the foundation of reconstruction.

After restoration of Poland's sovereignty, in the interwar period works were initiated to adapt and revitalize the area of the fortress and in the periods 1977-1984, 2007-2009 and 2011-2014 works such as reconstructions of the retaining structures were carried out. The objects of the complex of the Zamość Fortress, which we can visit nowadays, are the result of several centuries of extension, modification as well as decay and reconstruction in $19^{\text {th }}$ and $20^{\text {th }}$ century. The scale of the modern works, which to great extent are reconstructions, is shown on the aerial photo underneath, taken in 1927 (Fig. 2). It presents the cavaliers of the bastions VI and VII, although the bastions themselves as well as the walls connecting them are almost completely gone. Their contour can be recognized in the terrain formation but this shape cannot be compared with the present one. At present, the most important elements of the fortress are: VII Bastion with the cavalier and the defense wall, VI Bastion and the cavalier, The Szczebrzeszyn Gate, the Old Lviv Gate, the New Lviv Gate, The Old Lublin Gate, Kojec, the New Lublin Gate, the Rotunda and the Arsenal.

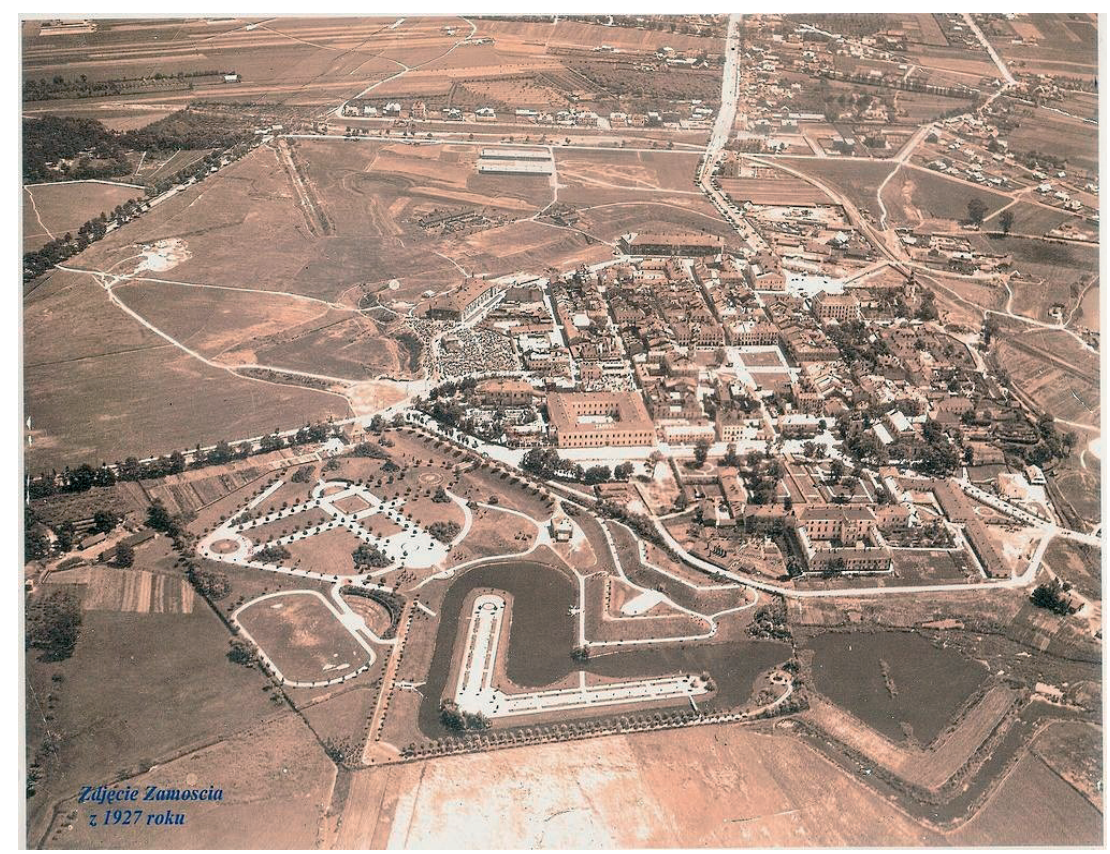

Fig. 2. Aerial photo of Zamość 1927 [http://fotopolska.eu/219844,foto.html?o=b32524]

The city planning of the complex has a chess-like grid of streets, which has not been significantly changed. The grid has two main clear axes of the Renaissance pattern: 
- The main axis directed at the Palace, connecting it with the city, crossing the center of the Great Square (at present Grodzka Street)

- The orthogonal axis, also crossing the center of the Great Square, connecting three markets (at present Bernard Morando Street).

The additional axis is what is toady Akademicka Street, situated in front of the Palace, connecting the Zamojski Academy and the Cathedral (former Collegiate church).

An important part of the urban space is constituted by three squares, whose origins go back to the initial urban plan of the town:

1. The Great Square measuring $100 \times 100$ meters with arcade frontage. It was a central point of the town, with the City Hall situated on it.

2. The Salt Market - with arcades on the eastern and northern frontage. A building erected in the 2 nd half of the 19th century interferes with the area of this square. The name derives from the salt imported from Wieliczka and Ruthenia, stored on the Square in the first years after the foundation of the town. ${ }^{2}$

3. The Water Market - initially hat the contour of a 50-meter sided square and Morando Street crossed it. Today, it is somewhat disfigured: the former eastern frontage does not exist and the western on has been moved. At present, a fountain occupies its central part; the surrounding tenements were created on the turn of the $19^{\text {th }}$ century.

Within the Old Town we can also identify the area in front of the Palace (former weapon square) and the area in front of the former entry gates.

This spatial arrangement can be interpreted according to Francesco di Gogio Martini's approach - that the layout of the city refers to human body as the most perfect creation (Fig. 3). This reference should be understood abstractly not literally and highlights the organic not formal relations. Thus it alludes to Vitruvius's concept. The terrain (its elevation, soil fertility, aqueducts or access to building materials) is the city's starting point. Some researchers believe that city plan of Zamość is based on Martini's concept: head - the Zamoyski Palace, abdomen - Great Market, heart - Cathedral, extremity - bastions/gates.

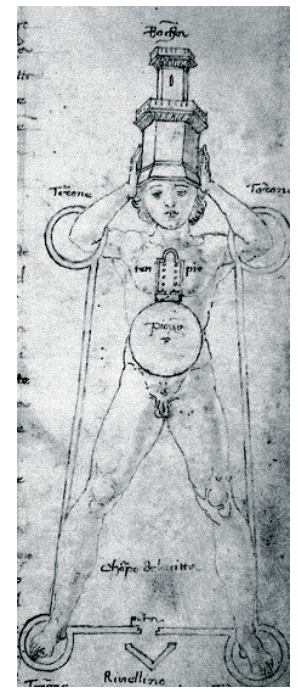

Fig. 3. Symbolic city scheme by Franceso di Giorgio Martin [Zarębska T., Teoria urbanistyki włoskiej XV i XVI wieku, Państwowe Wydawnictwo Naukowe, Warszawa 1971, s. 53 (in polish)]

2 Although, other sources report, that meat was the main product sold on that Square. 
Old Town's compact design is largely composed by 3- or 2- store brick buildings with few one-store buildings. The façade is colorful and diverse. The complete color range can be seen - warm and cool colors, pastel colors in different shades. The roofs are mainly covered with galvanized steel. The brick buildings that replaced the temporary wooden ones at the beginning of the city construction process, were mostly one-stored (or 1-2-stored), with their ridge to the road (this very form is present at the bukowiński painting and Zamość city plans from XVII century).

As the city developed along with the architectural skills the buildings got higher until their present cubature. The modern buildings composition is well preserved and recognizable (some parts do not exist anymore: two in north-west part of the city, few lateral parts which became monastery buildings during Baroque and the inner working parts and fortification).

According to the initial plans of Jan Zamoyski, all the tenement houses should be built correspondingly to Bernardo Morando's layout in order to ensure the order, aesthetic and regular structure of public space - which is characteristic for Renaissance architecture.

The most characteristic buildings of Zamość are ones close to the Great Market Square - on streets: Ormiańska 22 - Pod Madonną lub Sołtanowska, 24 - Pod Małżeństwem lub Szafirowa , 26 - Pod Aniołem, Pod Lwami lub Bartoszewiczów, 28 - Rudomiczowska and 30 - Wilczkowska. All of them were built in the first half of the 17th century perhaps replacing previous wooden ones. Excluding number 22 (2-store), they are 3-store buildings with characteristic rich decorations that are kept in Mannierist and early-Baroque style among which are: low-reliefs, flower and fruit friezes under the windows, ornamental framing of and the most unique element - attics.

The architecture of Zamość Old Town is rich in elements of particular meaning. These include, among others: Zamojski Palace, Zamojski Academy, Kolegia, Cerkiew (Orthodox church), fortress infrastructure. They reflect their multifunctionality and at the same time highlight the completeness of the conceptual program adopted while planning the city. Initially Zamość was combining various functions: living, defensive, judiciary and executive, was serving as a monarch residency but also center of education and trade and was a place where various religions and cultures met.

One of the most recognizable building in Zamość is the Zamoyski Palace. It was built in the early phase of the creation of the city - in years 1579-1586 according to Bernardo Morando's project. Originally it consisted of a palace located in the front and two tenement houses in the back (for founder's wife and her servants). This part was risen in years 1581-1583. It had rectangular shape, was 60 meters long, 2-stores with tower with a gallery and double-leaf staircase at Grand Market side. Previously the armory/arsenal was a part of Palace building complex, which nowadays consists of: Palace (3-stores), 2 pavilions (2-stores), 2 stables and 3 rear houses, one of which located in the back was connected with the palace by the closed galleries. It has thus regular and axial structure. Palace, pavilions and the rear houses form a U-shaped building symmetrically to the main axis which corresponds with the longitudinal, eastern-western axis of the city. The façade is homogeneously gray with no decoration. The current function of the building - it is the seat of the Regional and District Court whereas the rear houses serve as municipal flats. It has been considerably rebuilt and deprived of decorative elements during its transformation into Russian fortress (Fig. 4). Its by-gone beauty can be admired on available engravings.

Another landmark building, in both its form and function is the splendid Town Hall. It was designed in 1591 by Bernard Morando in Renaissance and baroque style. In years 1639-1651 it has been thoroughly rebuilt. Both the corpus and the tower were put up, the 
arcade was expanded. The building is based on a rectangular, 3-stores corpus and arched stairs $\left(1767-1770^{3}\right)$ leading to to main entrance on the second floor.

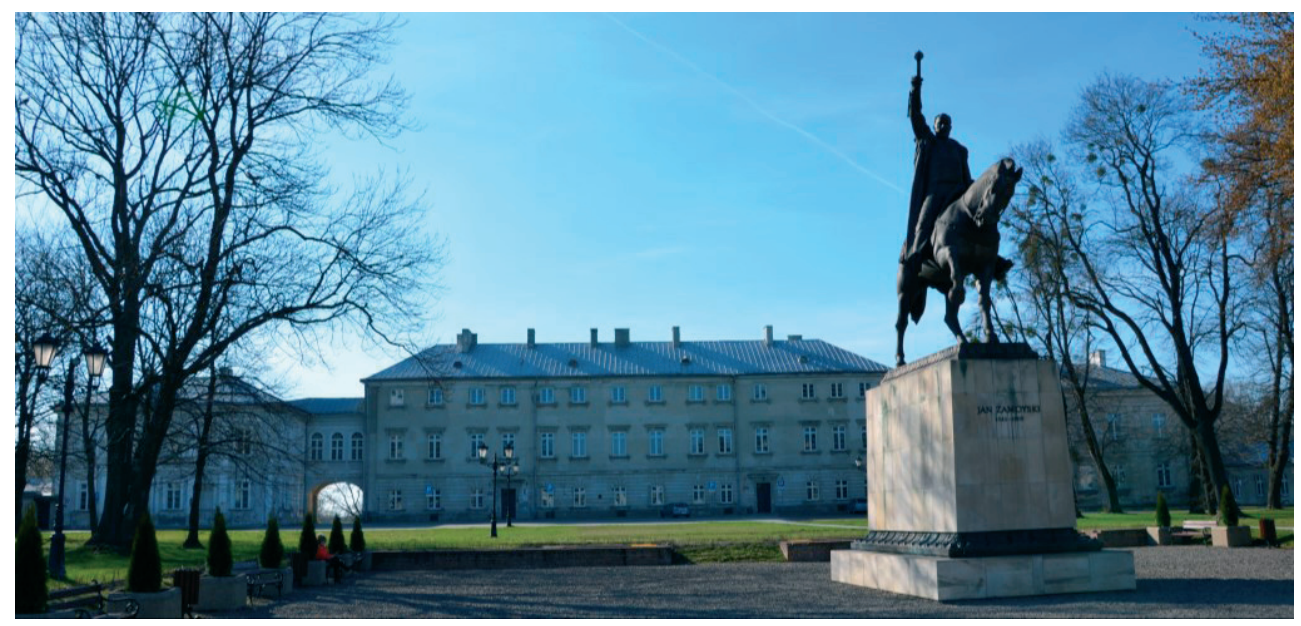

Fig. 4. Zamoyski Palace

An the top of the Town Hall we see 6-stores, quadrangular tower with helmet-like end and a light post. The Town Hall is build of red bricks with galvanized iron roof. Inner ceilings and stairs are made of iron and concrete. The ceilings on second and third floor are flat whereas the hallway and stairway have cross vaults. The front elevation is 7-axial, back elevation is 8 -axial and the lateral ones are 4-axial. Nowadays the building fulfills the administrative and tourist role. The building was reconstructed in the interwar period and thus obtained its present shape. The Town Hall and the stairs have been renovated in recent years.

The Zamojski Academy is another example of exceptional architecture, which unfortunately lost its original form and function. Its present form was developed during the re-constructional works in eighteen and nineteen century as well as the maintenance works early in the 20th century. It is a 2-stores brick building on a square plan, with square courtyard, with a 4-pitched roof, 13-axial façade with a broad rysalit and a stair-shaped gable. The Academy constructed in Jan Zamoyski's day was located in the same place, but was significantly smaller and design on a rectangular plan. Three wings of the building were added in seventeenth century and ornamented with attics. In the mid 18-th century the Academy was modernized by the Zamoyski architect Andrzej Bem - it became four-wing building and the attics were replaced by the high mansard roof according to the late Baroque styling. After the Academy's dissolution in 1784 the building was adapted to its new role: military barracks: the arcades in the courtyard were walled up, the mansard roofs replaced by pyramidal two-pitched roofs and the window frames knocked down. The ornaments and architectural details were removed and the previous internal division of the building changed. The Zamojski Academy was the third (along with Cracow Academy and Vilnus Academy) university in Poland. It was founded by Jan Zamoyski who continued to develop the university by establishing the school, library, printery and publishing house. It functioned in years 1595 to 1784 . The presence of the university considerably increased the importance and role of Zamość both regionally and nationally. Nowadays it serves as a general educa-

\footnotetext{
3 Thus this recognizable and characteristic element of city architecture does not come from the initial concept of city structure.
} 
tional liceum and Lifelong Learning Centre (Fig. 5). Due to planned investments its structure may be changed - it will get high, mansard roof covered with ceramic roofing tiles instead of previous sheet iron. The colors of the elevation will also be changed.

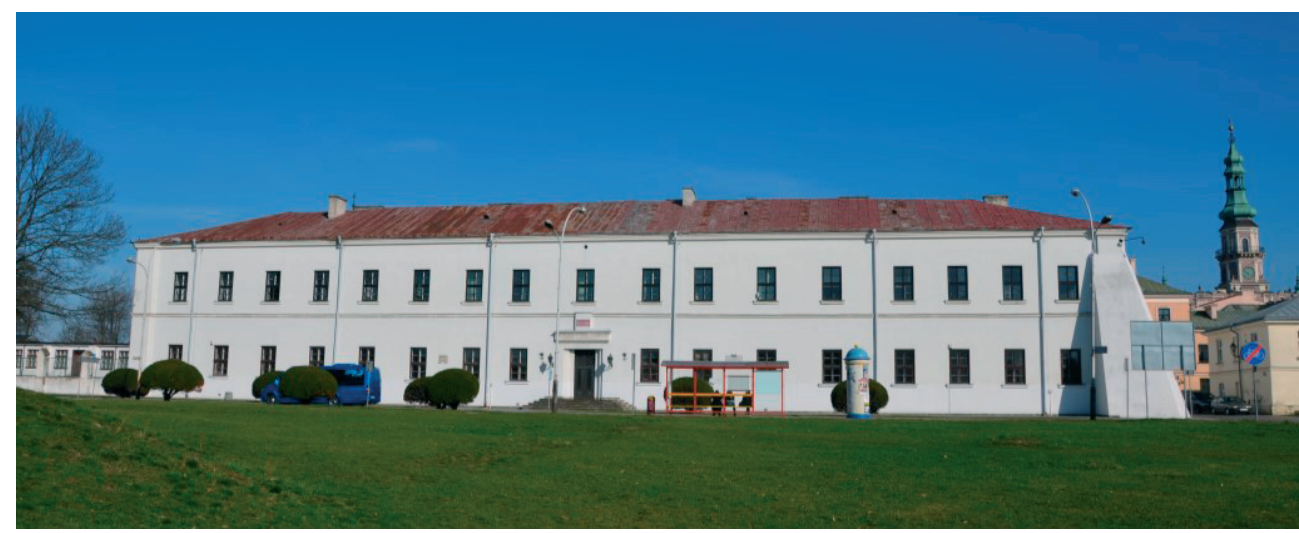

Fig. 5. Academy of Zamość

One of the greatest value of Zamość Old Town is its religious tolerance hence it is necessary to point out places of worship of different cultures and faiths. The main place is the Cathedral (a former collegiate church) dedicated to the Lord's Resurrection and St. Thomas the Apostle. It was built in 1587-1598 by Bernardo Morando. In years 1618-30 J. Jaroszewicz renovated the ornamentation of the vault and in years 1634-35 J. Falconi made a molding in Zamoyski chapel.

In $18^{\text {th }}$ century the porch and a ridge turret were built. In the first half of $19^{\text {th }}$ century it shared the fate of most buildings in Zamość - was rebuilt and lost its masterful decor. The brick church is oriented, with basilica-type layout, 3 naves and two rows of chapels and and a polygonally enclosed presbytery. The sacristy is on one side, the beautifully ornamented Zamoyski chapel on the other. The church preserved its rich furnishing (i.a. Church organs, altars from $17^{\text {th }}-19$ th century), many epitaphs and gravestones (i.a. Jan Zamoyski's gravestone from around 1618, Szymon Szymonowic's epitaph). Next to the Cathedral there is a stone, tower-like and 4-stores bell tower which replaced (in the second half of the $18^{\text {th }}$ century) previous, wooden one. In 1828 it was firstly lowered and then in 1930-31 overbuilt. It is crowned with a two-stage helmet, ball and a cross. The elevation is bossaged with broad pilasters and panels. There are 3 bells: "Jan" - 1662, "Wawrzyniec" - 1715 and "Tomasz" 1721.

On the other side of the Cathedral there is infułatka, built in $16^{\text {th }}$ century, designed by Bernardo Morando. Rebuilt several times it obtained its final form in year 1942. Nowadays it functions as a Diocesan museum with collections of liturgical vestments and objects. Due to planned investments the building will be rebuilt once more - new mansard roof will be higher and covered with ceramic tiles, the elevation color will be changed.

In Zamość we can also find the old Greek-Catholic Orthodox church, which currently became the Nikolai Roman Catholic Church. Built in 1589-1604 firstly as a wooden and then in 1618-31 (J. Jaroszewicz, J.Wolff) as a brick building, the church was renovated after a conflagration in the second half of $18^{\text {th }}$ century. The sanctuary is oriented, bricked, with 1 nave on a longitudinal plan. The characteristic elevation has a prominent entablature, pilasters, semicircular windows and 2 towers over the anticum: 3 -stores tower and octagonal tower with a light post. 
Zamość Synagogue was built in the first half of the $17^{\text {th }}$ century. This 1 -stores rectangular building has a prayer room and two atria. The external and internal walls and also the foundations are made of solid ceramic brick. The elevation is 2-axial with Tuscan styling. The building is ornamented with a decorative attics with a socle. Over the prayer room we find a butterfly roof (roof surfaces sloping down from opposing edges to a valley near the middle of the roof) and over the atria - pent roof. The final form was established during the reconstruction works in recent years. Close to the synagogue are located: mikvah (bath used for the purpose of ritual immersion in Judaism) and quahal.

Another important religious building is the Franciscan Temple. Built in years 1637-65 replaced the market owned by Bernardo Morando. Over the centuries it was rebuilt several times (i.a in 1672 after the fire). In years 1820-40 the inner structure was changed, in 1887 the gables were demolished and the main nave was lowered. The church is oriented build on a Latin cruciform plan. The unchanged part of the church (to the middle of the main nave) has a basilica form with 3 naves and 2-stores cellar. The main façade is 5-axial whereas the lateral ones are 6-axial. The elevation divided by niches, with a high socle and prominent entablature. Nowadays it combines 2 functions: sacral and educational (classrooms and sports hall are on the first floor). The reconstruction works aiming at restoring the original from will begin shortly.

In the proximity of the Franciscan Temple there is the Cloister of Fatebenefratelli "Podkarpie". It was founded by Jan Jakub Zamoyski and built in years 1756-73. In 1784 the Fatebenefratelli shared the fate of Capuchin Poor Clares, Franciscans and Order of Friars Minor - the cloister was closed. The name "Podkarpie" comes from the name of the inn ("Pod Karpiem" - "Karp" stands for carp) that used to located in the building. The cloister was situated in a south-eastern part of this four-winged and 1-stored edifice. The north-eastern part, that was built later is a 2 -stores, rectangular facility with a basement, attic and courtyard in the middle. Currently it has both living and economical function.

Built in the second half of the $17^{\text {th }}$ century in the Baroque style in line with J. M. Link's design, St. Catherine's Church was founded by Marcin Zamoyski and chorąży Hieronim Żaboklicki. After the first partition of Poland when Zamość was under Austrian rule, the monastery was dissolved ( $18^{\text {th }}$ century) the building served as a military depot. After city was taken by the Russians the cloister was demolished and the church building, as many others during the period of Partitions of Poland, deprived of its architectural value and classicist interior design (i.a. Signatures and Baroque roofs). What remained untouched were the groin vaults, pilasters and ornamented elements on the external walls. After Poland regained independence, for the short period of time a theater was located in the building, but eventually after the renovation in years 1925-1926 it became an academic church dedicated to St. Catherine. During World War II, "The Prussian Tribute", the famous Polish painting by Jan Matejko, was hidden in the vault of the church to protect it from the Nazis.

The old Poor Clares Church is a small, 1-nave, Baroque church. Founded by Anna Zamoyska, wife of Marcin Zamoyski in 1696, designed by J.M. Link. It adjoins the big, 3-winged Cloister built in years 1769-1774 founded by the Seventh Entailer Jan Jakub Zamoyski. After the monastery was dissolved the building has been passed to Franciscans and then to Daughters of Charity. The Church's function changed over the course of time: in 1817 is served as a military hospital, in the period between the wars as a police station, after the Second World War as a orphanage and nowadays the building houses the Karol Szymanowski National Music School of 1st and 2nd degree.

The place where once stood the Armenian Church is indicated by a special sign. This no longer existing building was built in 1645 from the collection of donations among the Armenians. It was a 1-nave and three-bay facility design according to a Latin cruciform plan. 
Next to the church we find a square tower which in an upper part takes octagonal form. The outer elevation was covered with pilasters, cornices, balustrated frieze and other decorative elements. In 1802, under the Austrian occupation the authorities dissolved the church and in years 1826-27 demolished the building. Today in that place there is a building of "Renesans" Hotel. In 1968 during the constructional works the church's foundations were discovered. Even though the Armenian Church does not exist anymore, it preserves its place in public urban space.

Another buildings connected with with a religious cult are Wikarówka (rebuilt several times, serves currently as a clergy house) and Seminary - founded in 1640 by Katarzyna Ostrogska Zamoyska, wife of Tomasz Zamoyski. Seminary was dissolved in 1784 and the building became the property of army. During the Congress Kingdom period it housed Corps of Engineers which under direction of general Jan Mallet-Malletski modernized and rebuilt the Zamość fortress. Currently it houses the Higher School for Management and Administration.

One of the most interesting elements of Zamość architecture are the market remains, which was constructed in the first phase of creating of the city. Today there are the cellars of Franciscan Church. The Market was called Morandowska due to the fact that its owner was at the same time the city constructor. It was a kind of inn for arriving merchants. It consisted of a two-stores house, stable and farm buildings. The name "giełda" ("guild") derives from "gildia" meaning the association of rich merchants which had its headquarters in that building. The building was erected in 1598. In 1625 the Second Entailer Tomasz Zamoyski bought it, demolished the facilities and handed the ground to Franciscans for erection of the church.

There are a lot of facilities that served sanitary functions, i.a wells, canals and a cistern. The first mentions about wells in Zamość date back to year 1581 . In $17^{\text {th }}$ century the wells were located in the yard of Zamoyski Academy, on every market, Fatebenefratelli cloister, in the yard of Zamoyski Palace and Chancel of Franciscans Church. After dissolving of the fortress new wells appeared - on Great Market Square and Salt Square. The only preserved remains of former wells can still be found in the former prison building. It was a brick well, 2 meters broad, 10.4 meters deep. It was built probably in $19^{\text {th }}$ century with prison buildings in order to provide water for the arrestees. Here we can also find an underground tank for rainwater (cistern from the $17^{\text {th }}$ century) with canals which might have been a part of vast system of water supply. It was particularly important for the city's hygiene and protection against fires. Stored water allowed frequent street cleaning (at that time the city lacked sufficient sewage system and the wastes were flooding the streets).

The "Piechowicz House" houses a still working(regardless the ownership changes) pharmacy that was found in 1609. It is the oldest polish pharmacy. At the end of the $19^{\text {th }}$ century it also housed a Hygienic Station, one of the very first laboratory examining food and water quality.

Old Town in Zamość also comprises buildings that were not included into the original city plan, for instance "Generałówka" - urban, neo-Renaissance Palace raised in years 1878-82, in line with Władysław Siennicki design, built for then-Chief of Zamość garrison. Currently the the building is in a very poor condition. In an adjacent tenement house Rosa Luxemburg was born. Another interesting building is called the "Central House" ("Centralka") - tenement house built in 1911-12 with a Secession-styled elevation. It was the very first electrified building in Zamość. It stands out in the city panorama due to its considerable height.

\footnotetext{
${ }^{4}$ Built by Szymon Piechowicz, a chemist and a professor of medicine at the Zamość Academy.
} 
From the description given above we can distinguish few spatial dominants which remained noticeable from the beginning of the city foundation. These are: Town Hall with its tower, The Cathedral (a former collegiate church), the Cathedral Bell Tower, Saint Catherine Church and Saint Nikolai Church. Former spacial dominants: Palace Tower (non-existent), the top of Franciscans Church (considerably lowered and rebuilt in the $19^{\text {th }}$ century; its reconstruction is planned), Armenian Church (non-existent).

World Heritage List also includes the interiors, used materials and substances as wall as the constructions of the buildings, equipment (historically preserved elements and additional museum objects) but does not refer to them directly.

\section{Outstanding universal value evaluation methodology 25 years ago}

Zamość Old Town in late 80s and early 90s was analyzed in terms of its outstanding universal value at the very beginning of the nomination process. At that time the most important document establishing the functioning of World Heritage system was Convention concerning the Protection of the World Cultural and Natural Heritage that entered into force on $17^{\text {th }}$ December 1975 in Paris ${ }^{5}$. This treaty comprehensively highlights its interest (Heritage of outstanding value) and the importance (it serves all humankind), aims and goals (protection and exploitation), the scope of responsibility (countries and international communities) as well as the general guidelines on goods evaluation (by given criteria and outstanding universal value evaluation).

The document that defines the nomination process and the procedure leading to inscription on World Heritage List, as well as the principles relating to functioning of individual institutions are the Operational Guidelines. Its first version was approved in 1977.

At the time of inscription of Old Town in Zamość on the World Heritage List, the main conditions were following:

1. Presenting outstanding universal value by meeting at least one out of six criteria included in Operational Guidelines.

2. Confirmation of authenticity of the site

3. Presenting the juridical mechanisms of protection and exploitation (Management System).

Based on these criteria, the proposal for inscription on the List was developed and submitted to Polish National Committee of ICOMOS in 1989. It was then directed to UNCESCO in 1990. The proposal included: 5 typed-written pages, inscription map, 2 photographs and a model. It was accepted in 1992 during the $16^{\text {th }}$ Session of the Committee in Santa Fe (USA).

The protection methods should be result from the value analysis. Broad definition of the value resulted in inaccurate protection guidelines. Therefore, the site was protected as a whole, without specifying its value carriers.

According to Operational Guidelines applicable at that time, comparative evaluation was necessary. However, in the initial years when the World Heritage List was being developed, this procedure was brief and the registered nominations were considered to be iconic and their value evident. That is why, the evaluation (based on criteria of relation of certain good with other, already existent) was rather professional and intuitive. As a result, the comparative objects/sites were not selected. Thus the elements that distinguish particular object from other and constitute its value were overlooked. That was the case of Zamość, when no other historic city was proposed to be comparative city.

5 Ratified by Poland on September 301976 r. (Dz.U.76.32.190). 
Analyzing the information presented during the application for inscribing on World Heritage List, one can state that it was conducted accordingly to the state of knowledge of that time. Nevertheless, it might not be enough as far as present requirements of protection and management of historical sites are concerned. UNESCO World Heritage Committee provided for that possibility, recommended that the Countries responsible for protection of particular goods should prepare or verify the declaration of outstanding universal value of all goods inscribed on the World Heritage List as well as expedite the management and protections system, including systematic monitoring. In case of Zamość new declaration of outstanding universal value was written. However, it still lacked a detailed comparative analysis.

The evolution of criteria of inscribing on World Heritage List caused that the present ones differ from the ones from 25 years ago. Whereas the Convention concerning the Protection of the World Cultural and Natural Heritage did not change, the Operational Guidelines evolved over the years. The difference can be observed in the numbers - the Operational Guidelines from 1988 included only 112 points while the present ones - 290 .

Table 1. Basic criteria of inscribing on World Heritage List

\begin{tabular}{lll}
\hline 25 years ago & Nowadays \\
\hline $\begin{array}{l}\text { Presenting outstanding universal value by meeting } \\
\text { at least one out of six criteria included in Opera- } \\
\text { tional Guidelines }\end{array}$ & $\begin{array}{l}\text { Presenting outstanding universal value by meeting at } \\
\text { least one out of six criteria included in Operational } \\
\text { Guidelines }\end{array}$ \\
\hline $\begin{array}{l}\text { Confirmation of good's authenticity } \\
\text { Presenting the juridical mechanisms of protection } \\
\text { and exploitation (Management System). }\end{array}$ & $\begin{array}{l}\text { Confirmation of good's } \\
\text { integrity }\end{array}$ & $\begin{array}{l}\text { Confirmation of good's } \\
\text { tion gonthenticity }\end{array}$ \\
\hline
\end{tabular}

From outward appearances it may seem as if the only change is adding one condition (integrity). Yet the change is far greater.

The first important change is a shift from intuitive value evaluation which was characteristic at the early stage of creation of World Heritage List. At that time, mainly iconic monuments were inscribed. This was the case of Zamość Old Town. Currently, a full comparative analysis with similar monuments is required.

Second significant change concerns the authenticity approach. Traditionally the authenticity of a monument was considered in relation with this monument's integrity and did not allow any changes. However, since introduction of Nara Document on Authenticity in 1994 a wide range of elements (such as: design, materials, function) is encouraged to be looked-into when judging a particular monument. As a consequence it is now possible to contrast the monument's features that absolutely need to be preserved, because they are value carriers and are authentic and integral with other features that could potentially be changed without harming the monument's value. For instance, recent investments in Zamość meet the modern definition of authenticity but would not be in line with the old one.

Another substantial change was adding in 2005 the condition of integrity. Until then it was not included in any definition of cultural goods. Investigation of integrity requires evaluation of:

- All elements needed for a historical site to be considered of outstanding universal value

- Monument's size in order to provide a proper care to its features and processes testifying to its significance

- Potential danger of development/negligence 
Furthermore, the requirement of management plan or management system, that defines how certain outstanding universal value should be protected, has also been changed. It is not enough to base the protection of monument exclusively on general legal regulations. It is henceforward necessary to present a separate document of "management plan" designed for a given historical site.

Taking all changes presented above into consideration, it was necessary to update previous declaration of value. That is why, in 2008 the declaration of outstanding universal value of Old Town in Zamość was updated. As a part of this update several potentially comparative cities were indicated. Nonetheless, a deep comparative analysis was not conducted.

New declaration of outstanding universal value looks as follows:

„Old City of Zamość in southeastern Poland is an outstanding example of a late 16th-century Central European town designed and built in accordance with Italian Renaissance theories on the creation of "ideal" cities. This innovative approach to town planning was the result of a very close cooperation between the town's enlightened founder and the distinguished Italian architect Bernardo Morando. The Old City of Zamość today retains its original rectilinear street plan and its unique blend of Italian and Central European architectural traditions, as well as parts of its encircling fortifications.

Located on the trade route linking western and northern Europe with the Black Sea, Zamość was conceived as a trade-based economic center. From the outset it was intended to be multinational, and had a high level of religious tolerance. It became the tangible reflection of the social and cultural ideas of the Renaissance, which were readily embraced in Poland, as exemplified by the establishment of a university (Zamość Academy) by Jan Zamoyski, the founder and owner of the town. His architect Bernardo Morando's city plan combined the functions of a residential palace, an urban ensemble, and a fortress, all in accordance with Renaissance concepts.

The Old City of Zamość has two distinct sections: on the west is the Zamoyski palace, and on the east is the town proper, laid out around three squares. The central Great Market Square, located at the junction of the town's two main axial streets, is enclosed by arcaded merchants' houses and anchored by a magnificent Town Hall. These and many other notable structures such as the cathedral, arsenal, and fortification gates illustrate a key feature of this great undertaking: a creative enhancement realized through the incorporation of artistic achievements attained in local architecture. The consistent implementation of Morando's plan over time has resulted in a stylistically homogeneous urban composition with a high level of architectural and landscape values."

It has been confirmed that a building, architectural ensemble, architectural or landscape sites satisfies the criteria of being of outstanding universal value, by fulfilling the $4^{\text {th }}$ criterion and reflects the importance of times it was built in.

The declaration states that:

„Zamość is an oustanding example of a Renaissance planned town of the late 16th century, which retains its original layout and fortifications and a large number of buildings of particular interest, blending Italian and Central European architectural traditions."

It is the exact notation as in previous World Heritage List inscription. Nonetheless, from a time perspective it may be concluded that the evaluation of Old Town in Zamość still is of a intuitive nature and relates to iconic good. That it why, the submission did not include a comparative analysis, which as a rule, should be essential for the evaluation of the criterion. Initially no comparative historical site was selected to which Old Town in Zamość could have been compared in order to prove its outstanding universal value. Thus, the condition of comparative analysis was not fulfilled, even though the intuitive evaluation seems to be obvious and indisputable. 
To sum up, the former documentation for inscription of Old Town in Zamość on UNESCO List (including the update) in regard to currently binding conditions:

- Lacked the comparative analysis and the justification of outstanding universal value was of intuitive nature

- The evaluation of authenticity and integrity was rather general (even after the update) and did not relate to the attributes of the monument as separate elements

- The Management System is based on general legal regulations and was not designed for particular historical site

Thus described value did not provide any preventive guidelines as far as the individual elements of the historical part of the city is concerned, but suggested the protection of the site as a whole. It determined the investment priorities of the historical site, the range and methods of conducted repair or modernization works. Nevertheless, this definition of Zamość Old Town was a basis for numerous investments and conservation works. In recent years the city acquired i.a: EU and EEA Financial Mechanism funds for 7 projects of nearly 170 millions PLN.

The most expensive project concerned the historical fortified landscape of Zamość Fortress from $16^{\text {th }}-19$ th century as a phenomenon of a large-scale space for defense purposes. The work field involved the the old Fortress, City Park and partly the infrastructure area (of total 45,7 hectares) and the main focus of the project was to protect, integrate, recompose, reconstruct and adapt these areas to touristic and cultural needs.

As a part of another project the museum group called The Museum of Fortification and Arms was created. The works were located close to Bastion III from $17^{\text {th }}$ century and included i.a.: the reconstruction of the fortification wall with creation of underground exhibition hall, modernization and renovation of historical site of Arsenal as well as the reconstruction of destroyed parts of the artillery magazine.

Numerous and significant, from city's perspective, renovations and restorations were made: tenement houses' frontages on Great Market Square from $18^{\text {th }}$ and $19^{\text {th }}$ century, slabs of Great Market Square, parts of the streets: Grodzka, Staszica, Moranda, Town Hall, several town houses with rear buildings, Bazyliańska street, attic on Great Market Square 5a, Centralka and following streets: Ormiańska, Żeromskiego, Kościuszki, Zamenhofa, Grecka and Pereca.

Another resources were channeled into restoration of 5 fortress infrastructure groups: Bastion VII, New Lublin Gate with adjacent wall, Old Lublin Gate with adjacent wall, postern and Kojec (additional fortification), Szczebrzeszyn Gate with wall, shooting gallery and gourdhouse and Kazamaty fortress (part of Bastion I). Results of the project are: 16 renovated historical sites and 13 historical sites adapted to cultural purposes.

The revitalization of Water Square, Salt Square with Jaroszewicz Square and adjacent streets as well as the restoration of the front elevation of the Town Hall with tower and staircase is another example of well invested funds. At the same time, the cellars of the Town Hall were adapted to the touristic needs.

All these efforts leading to city's importance gain were made not only by the local authorities. The Lord's Resurrection and Its Witness - St Thomas the Apostle Cathedral is responsible for renovation and reconstruction of the Cathedral historical building (the total cost of the renovation: 11 millions PLN). On the other hand, The Foundation For The Preservation Of Jewish Heritage completed investments of total value of 1.5 millions Euro which concerned comprehensive works in Zamość Synagogue as a part of the project Chassidic Route. Further works are planned: Zamoyski Academy (41.5 millions), Infułatka (13.5 millions) and Franciscans Church (23.86 millions). 


\section{Value assessment according to Smart Value methodology}

Smart Value is a form of thorough analysis of historical value and device enabling precise indication of value carriers. It represents a comprehensive and systematic approach to monument's value analysis, including all points of Operational Guidelines.

The SMART Value analysis assumptions can be divided into two levels. Firstly, overall value of the historical site (without any indication for its protection) needs to be defined, within a defined benchmark group. The evaluation itself consists of comparing a certain monument to selected set of objects (chosen as a reference group on the basis of the established criteria). Thus established value is relevant, as it is performed only with limited comparative group. We treat selected features as values and selected sites as valuable (as far as chosen group and comparative criteria are concerned).

Secondly, the monument's value needs to be analyzed (evaluation of the value of individual elements, by defining the value's attributes). The main goal of this action is finding the value carriers (defined on the first level). The attributes might be material and intangible. The external comparative analysis is not required.

This part of monument's value analysis is particularly important when the interference in the monument is required, in order to determine which elements and to what extend need to be protected.

Taking all conditions mentioned above, the Smart Value Evaluation comprises:

Level 1:

1. Analysis and profile of chosen site which enable to specify the elements in regard to which comparative group will be selected

2. Selecting the comparative group ( as a comparative reference )

3. Choosing the evaluation criteria - verification of the features that are crucial for the evaluation

4. Value evaluation (considering the criteria and comparative group)

Level 2:

1. Selecting the value's attributes

2. Evaluation of authenticity and integrity

3. Analysis of possible value change in case of modification of monument's elements

4. Formulation of guidelines for protection of particular site

Accordingly to the methodology described above, we present the analysis of Zamość Old Town in order to find the features which will determine the comparative group. Selected features are:

\begin{tabular}{ll}
\hline Analysis Range: & Whole Europe \\
\hline Date of construction or significant redevelopment: & 15th-17th century (first half of the 18th century) \\
\hline Function of the historical site : & City/ living \\
\hline Architectural and urban form: & $\begin{array}{l}\text { Deriving from the Renaissance (Renaissance concept } \\
\text { of the ideal city) }\end{array}$ \\
\hline "Material" Characterization of the historical site: & Brick buildings \\
\hline
\end{tabular}

Based on this characterization the comparative group, which would be a comparative context for Zamość Old Town was found. 20 cities were selected. 7 are currently inscribed on the UNESCO World Heritage List; these are: in Italy - Sabbioneta, Mantua, Pienza, Ferrara and Palmanova, in France - Neuf-Brisach and in Malta - La Valletta. Next two cities are in a 
comparative group for Palmanova: in Finland - Hamina and in the Netherlands - Coevorden (Coevarden e Naardan). Other cities, which meet the criteria of comparative group ${ }^{6}$ :

- Italy: Livorno, Gattinara, Terra del Sole, Grosso

- France: Vitry-le-Francois, Bergues, Charleville, Nancy

- Germany: Mannheim, Karlsruhe, Freudenstadt

- Croatia: Karlovac

- Netherlands: Bourtange

- Ukraine: Zhovkva, Stanyslaviv drawn:

Thanks to comparative analysis and precise criteria following conclusions can be

- "Establishing date" criterion - Old Town in Zamość is probably the first (excluding Italy) implementation of "Renaissance ideal city" on such a scale and on of the first that was constructed from scratch

- "Functions of the historical site" criterion - the most unique feature of Old Town in the implementation of Renaissance ideas not only in regard of the city architecture but also in regard of ideological program. As a result the city combined residential (including estate of Monarch), legislative, financial, educative, religious and cultural functions.

- "The spatial arrangement" criterion - Old Town in Zamość was one of the few cities settled on previously unoccupied terrain, founded in "cruda radice" instead of rearranging the already existent urban structures, which is absolutely unique.

- "Ideological program" criterion - the initial ideas are still visible in the urban composition of the city, which is not a common feature.

At this point of analysis following values of the historical site were identified:

Urban and architectural:

- One of the few cities founded in "cruda radice" (on the "raw roots") accordingly to the "Renaissance ideal city" concept.

- Military - an example of 16th century Fortress which has been modified according to the latest military knowledge and functioned until 19th century.

Symbolic value:

- City structure as a reflection of the ideological program of Renaissance ideal city. Zamość as the "Pearl of the Renaissance" and "Padua of the North"

- Zamość Fortress - was never captured in a battle by foreign troops (it was only captured by polish troops) - reason to be proud

Historic value:

- The city witnessed the local history, changes of the country's borders, development of science and culture, revolutions in religion

Social value:

- History of the city, life of Jan Zamoyski and Zamoyski family as a carrier of positive Renaissance social patterns in following areas: education, science, social coexistence and tolerance

${ }^{6}$ Having regard to discourses of Professor Andrzej Kadłuczka, Professor Zbigniew Myczkowski and PhD Jan Janczykowski presented during the conference "Protection and promotion of Zamość as an investment in National Heritage, 25 years on World Heritage List" $7^{\text {th }}$ September 2017 - Old Town was also compared with following cities: Guastala - Italy, Longwy, Phlasbourg - France, Willamstad - Netherlands, Kostrzyń nad Odrą - Poland/Germany. However, taking the analyzed reference group into consideration, the final evaluation of Old Town's value does not change. 
- Cultivation of city's tradition: military (combat reenactment) and educational (Zamoyski Academy - even after the changes of its function it is still present in public life. New revitalization program will help to adjust the building to new cultural and educational roles.

Taking into account all the mentioned above values, the superior value has been defined as follows: Old Town in Zamość is an outstanding example of Renaissance humanism ideas and development of the knowledge in planning and designing military buildings.

In the context of the city inscription on UNESCO World Heritage List this value was formulated as follows: Old Town in Zamość is an excellent example of Renaissance-designed city from the end of $16^{\text {th }}$ century that preserved its initial spatial arrangement, fortification and numerous buildings of great importance which combine the best architectural traditions of Italy and Middle Europe.

On the other hand, in the context of the city's recognition as a Historic Monument - it was proved that the city has historical, spatial, architectural and intangible values of a Renaissance city and of an outstanding achievement of European architecture of 16th century as well as the fortification group reflecting the evolution of military architecture from 16th to 19th century.

Having defined the values of monument it was possible to find its attributes, that is value carriers. It would not be possible without deeper analysis which specifies the carriers and the values they represent. On the other hand, breaking up the attributes into smaller parts and the evaluation of their authenticity and integrity enables the precise indication of value carriers. Analyzed attributes are: urban structure of the Renaissance city of Zamość, the fortifications, city localization, city surroundings, architecture - including form, function, panorama, views, public space, small architecture, surface, archaeological objects and intangible values.

Conclusions from deep analysis

Attributes that need to be preserved (reproduced)

The definition of attributes and evaluation of their authenticity and integrity enables choosing the ones that determine the value of Old Town and therefore need to be preserved. The most important are the original and authentic elements as well as the ones that are essential for monument's integrity. City development and growing needs of its inhabitants should not have negative influence on the value attributes acknowledged at the time of inscription on UNESCO World Heritage List. That is why, the values determine the actual extent of intervention works. Without these attributes Old Town in Zamość might loose its value.

Having regard to individual attributes and their specific elements it is recommended:

- Urban layout:

$\circ$ preservation of present infrastructure (streets and squares), including their course and sizes of currently existing buildings

$\circ$ preservation of compositional axes, including: their original course and avoiding interference with new elements

$\circ$ preservation of lucidity of the authentic city borders

- Fortification:

$\circ$ preservation and emphasis of relatively few authentic fortification elements

- Environment:

o the environment development within the borders of the buffer zone should enable the preservation of the site's value (including panoramas and views). Therefore, the buildings (heights and seizes) should be adopted in order to assure the city panorama.

- Panoramas and views

o preservation of at least already existing panoramas and viewing axes or if possible restoration of the original, historic ones (by removing modern elements 
hindering the access to panoramas and viewing axes or by recreating the non-existent elements). Adding new viewing dominants is irrational - it would reduce the lucidity and diminish the overall value of Old Town in Zamość.

- Existent buildings

Functions

○ preservation of the city parts that represent the historical functions. The buildings should at least with their form represent their historical functions. Nevertheless, forcing the former functions is both impossible and pointless.

Architectonic form

○ In general the architectonic form should not be changed, unless it is justified in terms of value sustain and the process would not reduce the authenticity. The size of the building should be considered equally with panoramas and views possible adjustments should not interfere with already existent panoramas and views. New dominants should not be created in order not to divert attention from old ones (it would be hard to explain that new dominants represent functions and values of the Renaissance concept.

- Having in mind that one of the most characteristic feature of the Renaissance concept was the harmony and stylistic unity of the city. Therefore, the reconstructive and modernisation works should stick to these ideas and do not cause unnecessary confusion.

Interior design and furnishing

○ making available all the interiors with original design and furnishing (with special reference to mobile monuments which are currently not available for visitors).

Architectural and landscape interiors

o Preservation of elements of small architecture in their historical form but keeping them from dominating the common space (with their size, colors, form and used materials)

- Preservation of parks in order to define the borders of the city and fortifications, spatial arrangement, panoramas and views

- Archaeological sites

○ Further research and work on monuments in Zamość is required as well as education and promotion of their function and value

- Intangible values

○ Further promotion of city's intangible assets by implementing "soft measures" (non-investment)

The extent of acceptable interventions and transformations

Having regard to attributes presented above that need to be preserved it is possible to set possible and acceptable intervention's extent. It will include all activities that will not influence the value, that is will not have negative impact on these attributes that are necessary for preservation of the value. Every investment or change of use might be assessed on the basis of its influence on the value of individual attributes and the results decide if they fall within the scope of acceptable interventions and transformations. The catalog of acceptable interventions is open.

For instance, it is possible to introduce a new building in place of the non-existent historical buildings as a complement to modern urban structure as well as historical spatial arrangement. However, it is form, design, size and used materials of individual project that will decide if the building can be introduced. Naturally, new buildings should allow the identification of already existing values and attributes, mentioned in previous parts of this article. At the same time, it should match with historically developed spatial arrangement, 
correspond aesthetically with architecture, preserve panoramas and views with its size and have functions that will not diminish the values of historical city center. Furthermore, new buildings should not introduce new spatial dominants in order not to interfere with the historical ones that reflect the ideas behind the city design. Without a doubt every investment idea should be examined individually as they may vary greatly from each other.

New buildings were introduced in the postwar period. In year 1956 new tenement house on Rynek 5 was built replacing the old, demolished one from 1830 (yellow elevation and attics ornamentation). This building became an integral part of the local landscape.

Guidelines for restoration works

The most important recommendation is the evaluation of possible consequences of restoration works on value attributes within a larger context of the historical site. Hence, the impact on the overall value of Old Town in Zamość should be considered not only from the point of view of individual monument but also its environment, views and panoramas.

- It is necessary that each restoration, renovation or modernization work is preceded by research on its potential influence (depending on the range of planned works on particular monument or part of historical site). In order to preserve the integrity of historical site the range of works should be evaluated with great care.

- With regard to planned investment concerning the Palace it is necessary to give this project priority and conduct public consultations as far as its new function is concerned $^{7}$. Furthermore, it is recommended to pursue the detailed examination on the historical, architectural and archaeological aspects of the building before the planned investment. Due to the fact that the investment may considerably change the form and design of the building it is necessary to bear in mind that the authenticity is a very important element of its value.

- It is advisable to further investigate the issue with the aim of improving knowledge relating to dating of objects that experienced considerable changes over the ages.

- In case of finding unidentified areas (e.g. underground tunnels and parts of fortification, cellars or potentially existing internal walls' ornamentation) further research is advisable.

$\underline{\text { Recommendations on the monument's utilization (adaptations, new functions, tourism) }}$

- Evaluation of undertaken actions with regard on their potential influence on various functions represented by the city. All works should include the necessity of preservation of the historical site value and its attributes.

- Currently, Old Town in Zamość is adopted for residential, administrative, sacral, educative, commercial and service, cultural and touristic (including the tourist information office) functions.

- In order to preserve the value it is advisable to maintain various functions of historical sites (residential, administrative, sacral, educative, commercial and service, cultural and touristic) primarily for the inhabitants. Replacing the residential function with commercial and touristic function might lead to loss of the importance of individual buildings. One can say, that on this relatively small area we observe a full array of functions characteristic for properly-functioning urban centers, which in case of Zamość results from the Renaissance concept of the city.

\footnotetext{
7 „Operational Guidelines for the Implementation of the World Heritage Convention”point to the fact that social participation in protection and care over the monuments is an important part of Management Plan and the authorities should encourage the society and stakeholders to active participation in these processes as these are crucial conditions for sustainable protection, conservation, administration and promotion.
} 
- Introduction of new functions is possible as long as it will not interfere with the value of historical site. From economical point of view, it is reasonable to develop the tourism services (restaurants, pubs, hotels, museums etc.) - this, however, should not result in disappearance of current functions or bringing out the inhabitants of Old Town in Zamość. The risk exists that the processes taking place in historical city centers (recently seen in polish cities: Cracow, Wrocław and Warsaw) lead to domination of tourism service sector on these areas. In the longer term, it may cause the elimination of the original idea, which was to create a perfect place to live. Focusing solely on tourists will induce the transfer of inhabitants out of Old Town and in consequence disappearance of services dedicated to them (e.g. photographer, tailor, haberdashery). On the other hand, the tourism infrastructure will not fully take their place. Thus, the city would not longer be a place in which people live with diversified social structure earning a living with trade, craft, industry and service and would become a touristic place for leisure activities. Total absence of original function will lead to worse understanding of used spatial solutions.

\section{Summary}

The main benefits of value assessment using Smart Value methodology:

- Improving knowledge of outstanding universal value in regard to comparative group

- Indication of aspects of outstanding universal value that distinguish particular historical site from among compared buildings

- Precise definition of attributes, their authenticity and integrity

- Creation of a basis for management plan for proper preservation of historical sites for future generations.

Consequently it is possible to define:

- The scope of possible interventions and changes

- Guidelines for conservation works, useful for setting conservation recommendations

- Guidelines for further research by presenting areas not sufficiently discovered

- Recommendations for proper utilization of historical sites (i.a. adaptation, new functions, scale and structure of the incoming tourism)

- Basis for management plan.

In accordance with the assumptions of Smart Value method the assessment should not be the only way of evaluation of historical site, because this methodology is primarily designed for evaluation of material features and their functions in the past. To a very limited extent it refers to present tangible and intangible assets as it is impossible to objectively define their grading and it is not a part of professional monument opinion. Creation of overall evaluation of monument's value that will include Smart Value and other methodologies may differ significantly from evaluation using exclusively Smart Value method. Therefore, following issues need to be analyzed:

- Should we allow new buildings to be constructed within the historical area? If so, under what conditions that will provide protection of outstanding universal value?

- Is it advisable to maintain historically developed but authentic form or restore the original one? Will it emphasize the value or will be a threat for authenticity acknowledged 25 years age?

- How to provide spatial order and harmony in case of new buildings or changes in already existing one? How to carry out the investment without negative influence on compositional axes, historical spatial dominants and viewing points? 
- What functions are guarantee for maintenance of value?

- Which elements of the value are the least popular? How to promote them?

Each of the above-mentioned questions can be related to the elements of the particular field of heritage. In summary, the current principles of analysis of monument enable a more precise definition of the tangible carriers of its value and authenticity. It is possible due to division of monument into elements, its attributes and separate assessment of the elements. This approach enables more precise description of the rules of protection and management of particular elements of a monument in the context of its current state and realized investments. Also, it makes it possible to define the elements which need to be maintained and others which can be subject to modifications (and the rules of this selection). This approach is more time-consuming, however it guarantees the maintenance of the value of the monument, with particular care over its outstanding authentic and integral elements. The effects of this approach will be appreciated by generations to come, who will have the chance to get to know and experience the extraordinary value of monuments.

\section{References}

1. Chorzęba J., Fortyfikacje, Grupa Wydawnicza PWN, Warszawa 2007.

2. Herbst S., Zamość, Budownictwo i Architektura, Warszawa 1954.

3. Kosim S. Zwycięskie bitwy Polaków. 1809 Zamość, Tom 63, Wydawnictwo Bellona, Warszawa 2016.

4. Lorentz E., Dziedzictwo Franciszkanów konwentualnych w Zamościu. Architektura Sztuka Historia, Parafia Rzymskokatolicka pw. Zwiastowania NMP OO. Franciszkanów Konwentualnych w Zamościu, Zamość 2016.

5. Paszkowski Z., Miasto idealne $w$ perspektywie europejskiej $i$ jego zwiazki z urbanistyka wspótczesna, Universitas, Kraków 2011.

6. Szmygin B., Światowe dziedzictwo kultury Unesco - charakterystyka, metodologia, zarzadzanie, Polski Komitet Narodowy ICOMOS, Politechnika Lubelska, Warszawa-Lublin 2016.

7. Witusik A.A., O Zamoyskich, Zamościu i Akademii Zamojskiej, Wydawnictwo Lubelskie, Lublin 1978.

8. Wyjątkowa uniwersalna wartość a monitoring dóbr światowego dziedzictwa, red. Szmygin B., Polski Komitet Narodowy ICOMOS i Narodowy Instytut Dziedzictwa, Warszawa 2011.

9. Zamość. Z przeszłości twierdzy i miasta, red. Koprukowniak A., Witusik A.A., Wydawnictwo Lubelskie, Lublin 1980.

10. Zarębska T., Teoria urbanistyki włoskiej XV i XVI wieku, Państwowe Wydawnictwo Naukowe, Warszawa 1971.

11. Zarębska T., Zamość - miasto idealne i jego realizacja [w:] Zamość miasto idealne, red. J. Kowalczyk, Wydawnictwo Lubelskie.

12. Feduszka J., Trasa turystyczna w podziemiach oficyny Ratusza Zamojskiego, Zamość 2010, http://muzeum-zamojskie.pl/wp-content/uploads/2009/10/Ratusza_przewodnik.pdf (1.04.2017 r.)

13. Kowalczyk J., Dzieje rozwoju przestrzennego i architektury Zamościa, Materiału z Sesji Naukowej (29-31 V 1978), Archiwariusz Zamojski 2005.

14. Kowalczyk J., Rekonstrukcja zabytków architektury w Zamościu, Ochrona Zabytków 46/3 (182) (1993) 210-222.

15. Pawlicki B.M., O Zamościu bez przemilczeń (idee ochrony zabytków), Teka Komisji Urbanistyki i Architektury PAN Oddział w Krakowie, TOM XLIII (2015) s. 41-63.

16. Szpakowska Ernestyna, Atlas miast idealnych. XVI-XVIII wiek, Politechnika Krakowska, Wydział Architektury.

17. Szpakowska E., Charakterystyka wybranych przykładów miast idealnych, motywowanych wizja społeczna, część I, Politechnika Krakowska, Wydział Architektury.

18. Twierdza Zamość, dzieje i renowacja fortyfikacji, Zamość 2009. 